\title{
"MY BUNCEE" : A WEB-BASED PRESENTATION TOOL TO IMPROVE ET-12 STUDENTS' MOTIVATION,ENGAGEMENT, AND ACHIEVEMENT
}

\author{
Diana Luspa \\ diana_luspa@yahoo.com \\ Lembaga Bahasa LIA, Palembang-Indonesia
}

\begin{abstract}
Abstarct: The Comet Series of textbooks for the Intermediate levels of LB LIA's English for Teens Program is prepared to suit the needs of students between thirteen and fifteen years of age. Despite this psychological breakthrough stage, students of ET-12 encountered some problems in understanding the value of the task to them, especially when they did the presentation task. It was found that they were less motivated and engaged to do it, and it influenced their achievement. In line with the principles behind the course, motivation and confidence, fun but more serious and insightful tasks are definitely things that the students need in order that the objectives of the teaching and learning are successfully achieved. To address the issues, Buncee application, a web-based presentation tool,was used to improve these students' motivation and engagement. How "Buncee" helpedthe students to achieve the goal was conducted in eight meetings. The process was recorded using observation, journal, and questionaires and the data was analyzed by using SPSS. The results showed that the Buncee was as an effective tool to improve students' motivation and engagement. Gen $Z$ is accustomed to personalize everything by choosing what they want (and just as important, what the don't want). These attitudes will inevitably influence education. Therefore,teachers need to adapt their pedagogical approaches.
\end{abstract}

Keywords: Buncee, Motivation, Engagement, Achievement

\section{INTRODUCTION}

The Comet Series of textbooks for the Intermediate levels of LB LIA's English for Teens Program is prepared to suit the needs of students between thirteen and fifteen years of age. Despite this psychological breakthrough stage, students of ET-12 encountered some problems in understanding the value of the task to them, especially when they did the presentation task. It was found 


\section{ESTEEM: JOURNAL OF ENGLISH STUDY PROGRAMME \\ P-ISSN 2622-9323 \\ E-ISSN 2622-2213}

that they were less motivated and engaged to do it, and eventually it influenced their achievement.

Motivating students is one of the major challenges teachers face on a daily basis. Conceptualized as students' energy and drive to engage, learn, work effectively, and achieve their potential at school, motivation and engagement play a large role in students' interest and enjoyment of school (Martin2006, pg cited Stephens 2015). Understandably, both also play huge roles in academic achievement (Martin 2001; Martin \& Marsh 2003, cited Stephens 2015). Consequently, those students who are motivated by and engaged in learning tend to perform considerably higher academically and are better behaved than unmotivated and un-engaged peers (Fredricks, Bulumenfeld, \& Paris 2004 cited Stephens 2015).

\section{LITERATURE REVIEW}

The purpose and importance of motivation should be clearly understood by the teacher. The fundamental aim of motivation is to stimulate and to facilitate learning activity.Learning is an active process that needs to be motivated and guided toward desirable ends (Mondal).For instance, if the
In line with the principles behind the course, motivation and confidence, fun but more serious and insightful tasks are definitely things that the students need in order that the objectives of the teaching and learning are successfully achieved. To address the issues, Buncee application, a web-based presentation tool, was used to improve these students' motivation, engagement, and achievement. Using Buncee motivates students to solve and create problem solving tasks, support inquiry and wonder and provide access to grade level content. It also helps students to demonstrate understanding of core content and instruction, along with promoting student engagement and self-motivation. We must create meaningful learning experiences for students with special needs and help build connections between the real world and academic learning ( Festa, 2016).

instructor can explain to the students how a specific subject matter can relate to real life situations, the students are more likely to have a personal interest in learning what's being presented to them.While some students are motivated by extrinsic factors, others may be motived purely by intrinsic 


\section{ESTEEM: JOURNAL OF ENGLISH STUDY PROGRAMME \\ P-ISSN 2622-9323 \\ E-ISSN 2622-2213}

factors. In these situations, the student may have a goal that they want to reach by a certain time. In order to accomplish their goals, the information that they learn is of great value to them ( Stedul, 2013).

Jaya (2017) Students must be actively engaged and show interest in classes to achieve effective learning in school. For this they must be highly motivated and interested in classes. What is expected from students during the teaching-learning process is to have intrinsic motivation and authentic engagement in classes. Therefore, teachers must be aware oftheir students' motivation and employ motivation strategies to ensure their authentic engagement in classes.Student engagement, a phenomenon that cannot be directly observed (Schlechty,2002 cited Nayir 2017), is a process that facilitates learning and increases academic success (Marks, 2000 cited Nayir 2017). Engagement is an important predictor of success. The more students engage them selves in academic activities, the more they will be successful (Harboura, Lauren, Chris \& Lindsay, 2015 cited Nayir 2017). The fact that students focus on assignments and subjects means that teachers have achieved their intended purpose and students are actively engaged in the learning process. An engaged student dedicates himself to the subject and performs with enthusiasm and care during thelearning process because he attributes a value to it. Even when faced with challenges while doing the assignment, a student continues to study and finds a personal value and meaning in his assignment (Schlechty, 2002 cited Nayir 2017). Student engagement also means a student's enthusiasm to engage in the learning process gives him a need to learn,voluntary engagement in learning, and the will to succeed (Bomia, Beluzo,Demeester, Elander, Johnson, \& Sheldon, 1997, p. 294 cited Nayir 2017).

Understandably, both also play huge roles in academic achievement (Martin 2001; Martin \& Marsh 2003, cited Stephens 2015). Consequently, those students who are motivated by and engaged in learning tend to perform considerably higher academically and are better behaved than unmotivated and un-engaged peers (Fredricks, Bulumenfeld, \& Paris 2004 cited Stephens 2015).

Motivating students in school can be challeging today, however, there is a classrooom tool that encourages digital natives to maintain interest and gain 


\section{ESTEEM: JOURNAL OF ENGLISH STUDY PROGRAMME \\ P-ISSN 2622-9323 \\ E-ISSN 2622-2213}

knowledge with relevant tasks. This creative collaborative tech tool is called buncee. Buncee is a web-based tool for creating interactive multmedia presentations. The user can integrate content from both external and internal sources as well as create content directly on each slide. In doing so, Buncee makes technology accesible to

both teachers and students of all proficiency levels. Using Buncee in a classroom has not only increased motivation, but has also engaged students to take steps towards their achievement. Just simply visit https://app.edu.buncee.com/ how to sign up Buncee.

\section{RESEARCH PROCEDURES}

The action research was conducted in 8 meetings. The data collection methods used in this study was observation, interview, teaching journal, questionnaire, and test as can be seen in Table 1.

Table 1

Teaching Journal

\begin{tabular}{|c|c|}
\hline Meeting & $\begin{array}{r}\text { Activity } \\
\end{array}$ \\
\hline 1 & $\begin{array}{l}\text { Lesson } 4 \text { ( } 1^{\text {st }} \text { meeting): Observation } \\
\text { - Students learned to talk about isolated tribes in Indonesia (or } \\
\text { elsewhere) } \\
\text { - Teacher explained some expressions used to start a talk, change a } \\
\text { talk, and end a talk. } \\
\text { - Students discussed with their groups to perform a talk on the next } \\
\text { meeting. (students seemed reluctant when they knew they would } \\
\text { performed a talk) }\end{array}$ \\
\hline 2 & $\begin{array}{l}\text { Lesson } 4 \text { ( } 2^{\text {nd }} \text { meeting): Observation \& Pre-test } \\
\text { - Students perfomed a talk. } \\
\text { - Teacher used oral presentation rubric to score the students' } \\
\text { presentation (appendix } 1 \text { ) that was used as the pre-test score. } \\
\text { - Students looked bored. (presenters and audience were not } \\
\text { interested in the activity) } \\
\text { - There was only one group out of } 5 \text { used media (pictures) } \\
\text { - There was one group out of five used one gadget (tablet to show }\end{array}$ \\
\hline
\end{tabular}




\begin{tabular}{|c|c|}
\hline & $\begin{array}{l}\text { the pictures), but it was not effective because audience could not } \\
\text { see it clearly. } \\
\text { - Three other groups presented the talk without using any media. } \\
\text { - It made some problems arose such as having no eye contact with } \\
\text { audience, speaking in low volume, being not able to grasp the } \\
\text { information, showing no interest in topic, having the failure of } \\
\text { engaging the audience and understanding of knowledge of the } \\
\text { topic. }\end{array}$ \\
\hline 3 & $\begin{array}{l}\text { Lesson } 6 \text { ( } 1^{\text {st }} \text { meeting): Observation and interview } \\
\text { - Teacher interviewed the students about doing a presentation. } \\
\text { Results of the interview: } \\
\text { - Students stated that they started doing a presentation when they } \\
\text { were in ET-4 level. } \\
\text { - Some students like doing a presentation individually and some like } \\
\text { doing it in a group. } \\
\text { - Students who liked delivering a presentation individually said that it } \\
\text { was because they didn't want the other students just relied on } \\
\text { them to prepare the presentation. } \\
\text { - Students who liked doing a presentation in a group said that it was } \\
\text { because they could choose which parts they wanted to present } \\
\text { because the rest would be presented by others. Others said that } \\
\text { they could rely on their group to prepare the presentation. } \\
\text { - Students said that doing a presentation in a group did not really } \\
\text { give them opportunity to help each other because sometimes only } \\
\text { one or two people worked on the presentation. } \\
\text { - Students said that they didn't use any media when they presented } \\
\text { because they didn't discuss about preparing it. They just focused } \\
\text { on which part was going to be presented by each person. } \\
\text { Students said that they didn't pay attention to their friends' } \\
\text { surprisingly, students said they were bored to do a presentation }\end{array}$ \\
\hline
\end{tabular}




\begin{tabular}{|c|c|}
\hline & $\begin{array}{l}\text { because they always did that before. } \\
\text { - Students said that if they were absent on the day to perform, they } \\
\text { just could skip their performance, free from their responsibility to } \\
\text { present. } \\
\text { - In this lesson,Students learned how to give a valedictory speech } \\
\text { - Teacher gave students some options how would they perform their } \\
\text { valedictory speech, to perform it live in front of public in the lobby, } \\
\text { to perform it in their class live, or to record it using "BUNCEE", a } \\
\text { web-based tool for creating interactive multmedia presentations. } \\
\text { - Teacher introduced "Buncee" and explained how to use it to } \\
\text { students. } \\
\text { - Ttudents prefered to use Buncee for their performance. } \\
\text { because it was made using a web-based tool. }\end{array}$ \\
\hline 4 & $\begin{array}{l}\left.\text { Lesson 6(2 }{ }^{\text {nd }} \text { meeting }\right) \text { : } \\
\text { - Teacher gave students opportunity to see their friends' valedictory } \\
\text { speech on Buncee. } \\
\text { - Teacher and students could give oral and written feedback to the } \\
\text { students' presentation using features provided on their buncee. } \\
\text { - Students could edit and share the links of their first Buncee. } \\
\text { - One of examples of the student's Buncee } \\
\underline{\text { https://app.edu.buncee.com/buncee/f16f5e3ed4e4408fa51c11e0f3 }} \\
\underline{1 \mathrm{fd} 2 \mathrm{~b} 9}\end{array}$ \\
\hline 5 & $\begin{array}{l}\text { Lesson } 7\left(1^{\text {st }} \text { meeting): }\right. \\
\text { - Students learned to handle questions about traditional textiles. } \\
\text { - Students used the expressions of giving a talk (review) and } \\
\text { expressions for handling a talk. } \\
\text { - Teachers asked students in groups to present about other } \\
\text { traditional textiles using Buncee }\end{array}$ \\
\hline 6 & $\begin{array}{l}\text { Lesson } 7 \text { ( } 2^{\text {nd }} \text { meeting): } \\
\text { - Students used buncee slides and performed their presentation } \\
\text { lived. }\end{array}$ \\
\hline
\end{tabular}


ESTEEM: JOURNAL OF ENGLISH STUDY PROGRAMME

P-ISSN 2622-9323

E-ISSN 2622-2213

\begin{tabular}{|c|c|}
\hline & $\begin{array}{l}\text { - Teacher and other students gave feedback. } \\
\text { - One of examples of the student's buncee } \\
\text { https://app.edu.buncee.com/buncee/41ddf325eb4c4c6082491b6b8 } \\
\underline{48 c 9787}\end{array}$ \\
\hline 7 & $\begin{array}{l}\text { Lesson 9: } \\
\text { - Students learned to talk about traditional costumes } \\
\text { - Teacher introduced the format of presentation that could be used } \\
\text { - } \text { as the outline. } \\
\text { - Students could choose to present it in groups or individually. }\end{array}$ \\
\hline 8 & 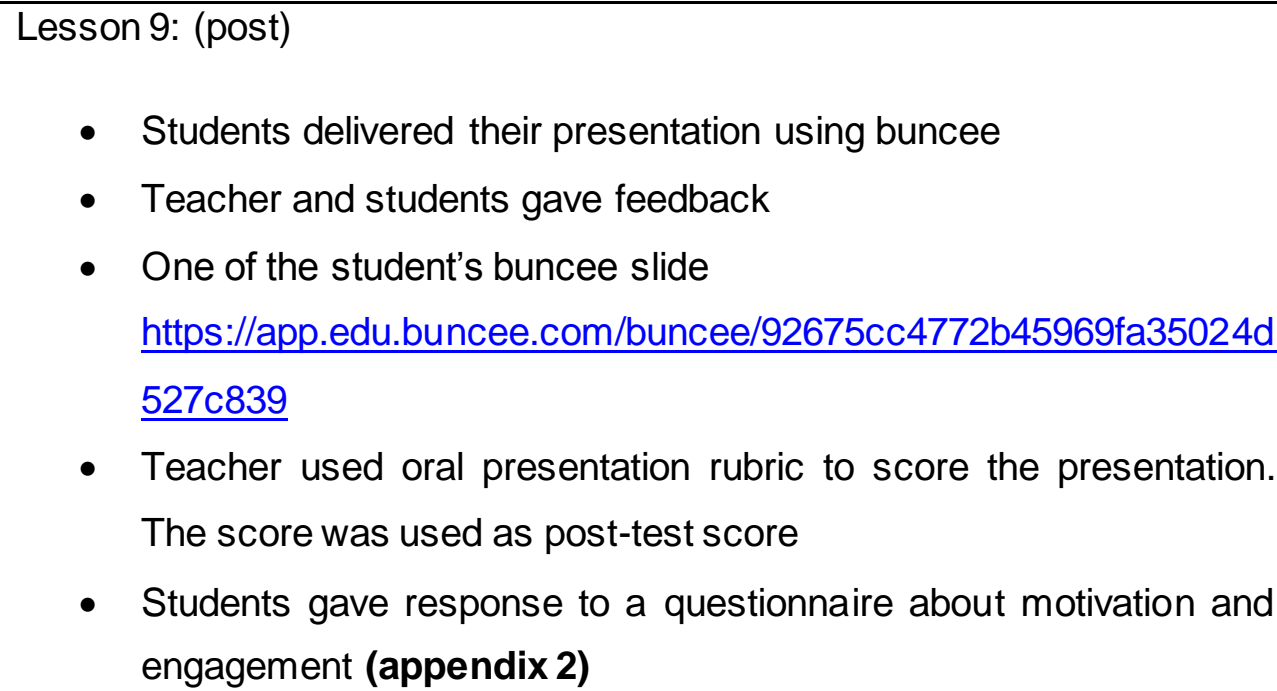 \\
\hline
\end{tabular}

this study to analyze the data from the

questionnaires and tests. In analyzing

the data, the writer used SPSS 23 for

Windows.

An oral presentation rubric was used to collect the pre-test and posttest data. The results of pre-test and post-test compared by using t-test. As a result, it was known whether or not terms of students' achievement in doing a presentation using Buncee.

A questionnaire was distributed in this study (See appendix 3). The purpose of giving this to them was to know whether or not Buncee could motivate and engage the students in learning process. 
ESTEEM: JOURNAL OF ENGLISH STUDY PROGRAMME

\section{P-ISSN 2622-9323}

E-ISSN 2622-2213

The outline of scoring of the

questionnaire can be seen below:

Table 2

Scoring System of Questionnaire of Motivation and Engagement

\begin{tabular}{|c|c|c|c|c|c|c|c|}
\hline \multirow[t]{2}{*}{ No } & \multirow[t]{2}{*}{ STATEMENTS } & \multirow[t]{2}{*}{ ITEMS } & \multicolumn{5}{|c|}{ SCORING } \\
\hline & & & $\begin{array}{l}\text { Strongly } \\
\text { disagree }\end{array}$ & Disagree & Neutral & agree & $\begin{array}{l}\text { Strongly } \\
\text { agree }\end{array}$ \\
\hline 1 & POSITIVE & $\begin{array}{l}1,2,3,4 \\
, 5,6,7 \\
9,12,1 \\
3,14,1 \\
5,16,1 \\
7,18,1 \\
9,20,2 \\
1,22,2 \\
3,24,2 \\
5,26,2 \\
7,28,2 \\
9,30\end{array}$ & 1 & 2 & 3 & 4 & 5 \\
\hline 2 & NEGATIVE & $\begin{array}{l}8,10,1 \\
1\end{array}$ & 5 & 4 & 3 & 2 & 1 \\
\hline
\end{tabular}

\section{FINDING AND INTERPRETATION}

Based on the results of the data analysis, the following is the interpretation to strengthen the value of the study. The interpretation covers: is Buncee, a web-based tool for presentation effective to improve 


\section{ESTEEM: JOURNAL OF ENGLISH STUDY PROGRAMME}

\section{P-ISSN 2622-9323 \\ E-ISSN 2622-2213}

students' motivation, engagement, and achievement?

Based on the data analysis, the lowest score of the pretest was 4 and the highest score of the pretest was 16 . Whereas, the lowest score of the

posttest was 8 . And, the highest score of the posttest was 16. In additional, the result of the pretest mean score was 8.26 , and the result of the posttest mean score was 13.16 , as can be seen in table 3.

Table 3

Descriptive Statistics

\begin{tabular}{|l|r|r|r|r|r|r|}
\hline & N & Minimum & Maximum & Sum & Mean & Std. Deviation \\
\hline pretest & 19 & 4 & 16 & 157 & 8,26 & 3,106 \\
posttest & 19 & 8 & 16 & 250 & 13,16 & 2,566 \\
Valid N (listwise) & 19 & & & & & \\
\hline
\end{tabular}

The significance level was .000. It showed that there was an improvement indicated by the results of the posttest. As can be seen in Table 4

Table 4

Paired Samples Correlations

\begin{tabular}{|l|r|r|r|}
\hline & N & Correlation & \multicolumn{1}{c|}{ Sig. } \\
\hline Pair $1 \quad$ pretest \& posttest & 19 &, 726 &, 000 \\
\hline
\end{tabular}

\begin{tabular}{|c|c|c|c|c|c|}
\hline \multicolumn{7}{|c|}{ Questionnaire Score } \\
\hline No & 1 & 2 & 3 & 4 & 5 \\
\hline 1 & & 1 & 8 & 26 & 5 \\
\hline 2 & & 1 & 7 & 26 & 6 \\
\hline 3 & & 1 & 7 & 26 & 6 \\
\hline 4 & & 2 & 12 & 19 & 7 \\
\hline 5 & & & 12 & 25 & 3 \\
\hline
\end{tabular}


ESTEEM: JOURNAL OF ENGLISH STUDY PROGRAMME

\section{P-ISSN 2622-9323}

E-ISSN 2622-2213

\begin{tabular}{|c|c|c|c|c|c|}
6 & & 1 & 15 & 17 & 7 \\
\hline 7 & & 2 & 21 & 17 & \\
\hline 8 & & 1 & 9 & 25 & 5 \\
\hline 9 & & 2 & 23 & 15 & \\
\hline 10 & & 1 & 27 & 12 & \\
\hline 11 & & 2 & 21 & 10 & 7 \\
\hline 12 & & 1 & 11 & 28 & \\
\hline 13 & & 1 & 8 & 31 & \\
\hline 14 & & 1 & 9 & 30 & \\
\hline 15 & & 3 & 9 & 14 & 14 \\
\hline 16 & & 1 & 11 & 28 & \\
\hline 17 & & & 12 & 28 & \\
\hline 18 & & & 3 & 36 & 1 \\
\hline 19 & & & 14 & 23 & 3 \\
\hline & Total & 21 & 239 & 436 & 64 \\
\hline & & & & & \\
\hline
\end{tabular}

Moreover, the results of questionnaire of motivation and engagement in using Buncee strengthen the value of the study (Table 5)

\section{Table 5}

The scores of the questionnaire were interpreted as in chart 1

\section{Chart 1}




\section{ESTEEM: JOURNAL OF ENGLISH STUDY PROGRAMME \\ P-ISSN 2622-9323 \\ E-ISSN 2622-2213}

\section{Questionnaire Analysis}

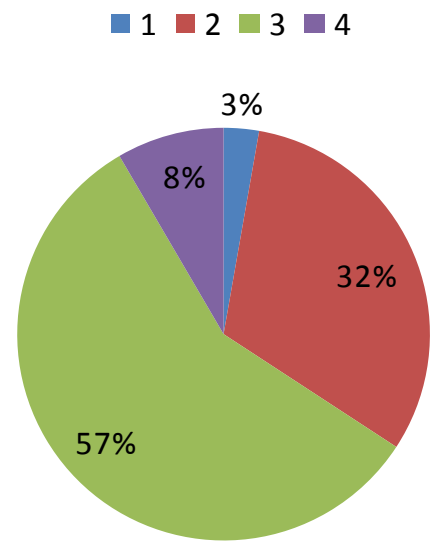

$3 \%$ of the total students disagreed with the statements, $8 \%$ of the total students didn't agree nor agree , $57 \%$ of the total students agreed with the statements, and $32 \%$ of the total students strongly agreed with the statements.

In short, Buncee, a web-based presentation tool can significantly improve students' motivation, engagement, and achievement.

\section{CONCLUSION}

Gen $Z$ is accustomed to personalize everything by choosing what they want (and just as important, what the don't want). They all learn in a different way at a dufferent pace. These attitudes will inevitably influence education. Therefore,teachers need to adapt their pedagogical approaches. Buncee offers ways to help build students' motivation, engagement,and eventually achievement. In short, Varying your approach can make it more enjoyable and encourage students to participate more fully.

\section{REFERENCES}

Jaya, A. 2017. The Influence of Teachers' Questioning Strategies on the Eleventh Grade Students' Speaking Achievement at SMKN 1 Palembang.Jambi-English Language Teaching. 2 (1). 


\section{ESTEEM: JOURNAL OF ENGLISH STUDY PROGRAMME \\ P-ISSN 2622-9323 \\ E-ISSN 2622-2213}

Kubischta, Frauke (2014). Engagement and Motivation : Questioning students on study-motivation, engagement and study strategies. Retrieved from https://www.theseus.fi/bitstream/handle/10024/78341/Kubischta\%20Frauke\%20Fin al. pdf? sequence $=1 \&$ isAllowed $=y$

Mondal, Puja (n.d). Importance of motivation in learning. Retrieved from http://www.yourarticlelibrary.com/motivation/importance-of-motivation-inlearning-657-words/5998

Nayir, Funda (2017). The relationship between students' motivation and class engagement. Eurisian Journal Educational Research 71 (2017) 59-78. Retrieved from www.ejer.comtr

Stedul, Mary (2013). How motivation affects learning. The inspire classroom, JL Marketing NH,LLc,2013. Retrieved from https://theinspiredclassroom.com/2013/07/how-motivation-affects-learning/

\section{Appendix 1}


ESTEEM: JOURNAL OF ENGLISH STUDY PROGRAMME

\section{P-ISSN 2622-9323}

E-ISSN 2622-2213

\begin{tabular}{|c|c|c|c|c|}
\hline \multicolumn{5}{|c|}{ Oral Presentation Rubric } \\
\hline & 4-Excellent & 3-Good & 2-Fair & 1-Needs Improvement \\
\hline Delivery & $\begin{array}{l}\text { - Holds attention of entire } \\
\text { audience with the use of } \\
\text { direct eye contact, seldom } \\
\text { looking at notes } \\
\text { - Speaks with fluctuation in } \\
\text { volume and inflection to } \\
\text { maintain audience interest } \\
\text { and emphasize key points } \\
\end{array}$ & $\begin{array}{l}\text { - Consistent use of direct eye } \\
\text { contact with audience, but } \\
\text { still returns to notes } \\
\text { - Speaks with satisfactory } \\
\text { variation of volume and } \\
\text { inflection }\end{array}$ & $\begin{array}{l}\text { - Displays minimal eye } \\
\text { contact with audience, } \\
\text { while reading mostly from } \\
\text { the notes } \\
\text { - Speaks in uneven volume } \\
\text { with little or no inflection }\end{array}$ & $\begin{array}{l}\cdot \text { Holds no eye contact with } \\
\text { audience, as entire report is } \\
\text { read from notes } \\
\text { - Speaks in low volume and/ } \\
\text { or monotonous tone, } \\
\text { which causes audience to } \\
\text { disengage }\end{array}$ \\
\hline $\begin{array}{l}\text { Content/ } \\
\text { Organization }\end{array}$ & $\begin{array}{l}\text { - Demonstrates full } \\
\text { knowledge by answering } \\
\text { all class questions } \\
\text { with explanations and } \\
\text { elaboration } \\
\text { - Provides clear purpose and } \\
\text { subject, pertinent examples, } \\
\text { facts, and/or statistics; } \\
\text { supports conclusions/ideas } \\
\text { with evidence }\end{array}$ & $\begin{array}{l}\text { - Is at ease with expected } \\
\text { answers to all questions, } \\
\text { without elaboration } \\
\text { - Has somewhat clear } \\
\text { purpose and subject, some } \\
\text { examples, facts, and/or } \\
\text { statistics that support the } \\
\text { subject, includes some data } \\
\text { or evidence that supports } \\
\text { conclusions }\end{array}$ & $\begin{array}{l}\text { - Is uncomfortable with } \\
\text { information and is able to } \\
\text { answer only rudimentary } \\
\text { questions } \\
\text { - Attempts to define purpose } \\
\text { and subject; provides } \\
\text { weak examples, facts, and } \\
\text { or statistics, which do not } \\
\text { adequately support the } \\
\text { subject; includes very thin } \\
\text { data or evidence }\end{array}$ & $\begin{array}{l}\text { - Does not have grasp of } \\
\text { information and cannot } \\
\text { answer questions about } \\
\text { subject } \\
\text { - Does not clearly define } \\
\text { subject and purpose; } \\
\text { provides weak or no } \\
\text { support of subject; gives } \\
\text { insufficient support for ideas } \\
\text { or conclusions }\end{array}$ \\
\hline $\begin{array}{l}\text { Enthusiasm/ } \\
\text { Audience } \\
\text { Awareness }\end{array}$ & $\begin{array}{l}\text { - Demonstrates strong } \\
\text { enthusiasm about topic } \\
\text { during entire presentation } \\
\text { - Significantly increases } \\
\text { audience understanding } \\
\text { and knowledge of topic; } \\
\text { convinces an audience to } \\
\text { recognize the validity and } \\
\text { importance of the subject }\end{array}$ & $\begin{array}{l}\text { - Shows some enthusiastic } \\
\text { feelings about topic } \\
\text { - Raises audience } \\
\text { understanding and } \\
\text { awareness of most points }\end{array}$ & $\begin{array}{l}\text { - Shows little or mixed } \\
\text { feelings about the topic } \\
\text { being presented } \\
\text { - Raises audience } \\
\text { understanding and } \\
\text { knowledge of some points }\end{array}$ & $\begin{array}{l}\text { - Shows no interest in topic } \\
\text { presented } \\
\text { - Fails to increase audience } \\
\text { understanding of } \\
\text { knowledge of topic }\end{array}$ \\
\hline $\begin{array}{l}\text { Use of } \\
\text { media }\end{array}$ & $\begin{array}{l}\text { - Visual aid is clear, relevant and } \\
\text { well-designed. } \\
\text { - Creative effort is evident in } \\
\text { making the presentation more } \\
\text { captivating. }\end{array}$ & $\begin{array}{l}\cdot \text { Most visual are clear and/or } \\
\text { relevant. } \\
\cdot \text { use of media is effective and } \\
\text { professional. }\end{array}$ & $\begin{array}{l}\text { Most visual are less clear } \\
\text { and or less relevant. } \\
\text { use of media is less effective } \\
\text { and less professional. }\end{array}$ & $\begin{array}{l}\text { - Most visual are not clear and/or not } \\
\text { relevant. } \\
\cdot \text { use of media is not effective and not } \\
\text { professional. }\end{array}$ \\
\hline
\end{tabular}

read writethink ,

\section{Appendix 2}




\section{ESTEEM: JOURNAL OF ENGLISH STUDY PROGRAMME \\ P-ISSN 2622-9323 \\ E-ISSN 2622-2213}

\section{QUESTIONNAIRE : Motivation and Engagement}

This questionnaire is anonymous.Please do not write your name, or any other comments that will make you identifiable on it. By completing this questionnaire you are consenting to take part in this research.

Please rate the items according to the following response format.

$1=$ strongly disagree $\quad 2=$ disagree $\quad 3=$ neutral $\quad 4=$ agree $\quad 5=$ strongly agree

\begin{tabular}{|l|l|l|l|l|l|l|}
\hline No & For my presentation.... & 1 & 2 & 3 & 4 & 5 \\
\hline 1 & I study hard as much as I can & & & & & \\
\hline 2 & I think about what I want to present in my class & & & & & \\
\hline 3 & $\begin{array}{l}\text { I set for myself high scores which I believe I can } \\
\text { achieve when doing a presentation }\end{array}$ & & & & & \\
\hline 4 & I try different ways to do a presentation & & & & & \\
\hline 5 & $\begin{array}{l}\text { When I do a presentation well, I work hard to make it } \\
\text { better }\end{array}$ & & & & \\
\hline 6 & $\begin{array}{l}\text { If I don't attain my goals to do a presentation, I try } \\
\text { again and again }\end{array}$ & & & & & \\
\hline 7 & I do study outside (beyond) class homework & & & & & \\
\hline 8 & I just aim to complete my task to do a presentation & & & & & \\
\hline 9 & $\begin{array}{l}\text { I try to do all efforts which I think I might succeed my } \\
\text { presentation }\end{array}$ & & & & & \\
\hline 10 & $\begin{array}{l}\text { I attempt only the average of my studies which I might } \\
\text { succeed my presentation }\end{array}$ & & & & \\
\hline 11 & $\begin{array}{l}\text { I only choose the easy parts of presentation which I } \\
\text { think I will succeed }\end{array}$ & & & & & \\
\hline 12 & $\begin{array}{l}\text { I make strong demand on myself to do a presentation } \\
\text { well }\end{array}$ & & & & & \\
\hline 13 & I prepare myself to do a presentation well & & & & & \\
\hline 14 & $\begin{array}{l}\text { When I have no enough time to prepare, I think about } \\
\text { the importance of doing a presentation for my future } \\
\text { academic and work life }\end{array}$ & & & & & \\
\hline 15 & I have confidence That I do my presentation well & & & & & \\
\hline 16 & $\begin{array}{l}\text { I receive encouragement on my presentation from my } \\
\text { teachers }\end{array}$ & & & & & \\
\hline 17 & I receive encouragement from at least one friend & & & & & \\
\hline 18 & I show genuine interest in doing a presentation & & & & & \\
\hline 19 & $\begin{array}{l}\text { I get interested in question and answer session as } \\
\text { well as the topic }\end{array}$ & & & & & \\
\hline 20 & I get honor and praise from my friends and teachers & & & & & \\
\hline 21 & I participate in classrooms discussions & & & & \\
\hline 22 & I participate in small group work/discussions \\
\hline 23 & $\begin{array}{l}\text { I ask questions on topics I do not understand from } \\
\text { others }\end{array}$ & & & & & \\
\hline 24 & I try to learn from others who are better than me & & & & & \\
\hline 25 & I seek help from experts (e.g., teachers) & & & & \\
\hline
\end{tabular}




\section{ESTEEM: JOURNAL OF ENGLISH STUDY PROGRAMME}

\section{P-ISSN 2622-9323}

E-ISSN 2622-2213

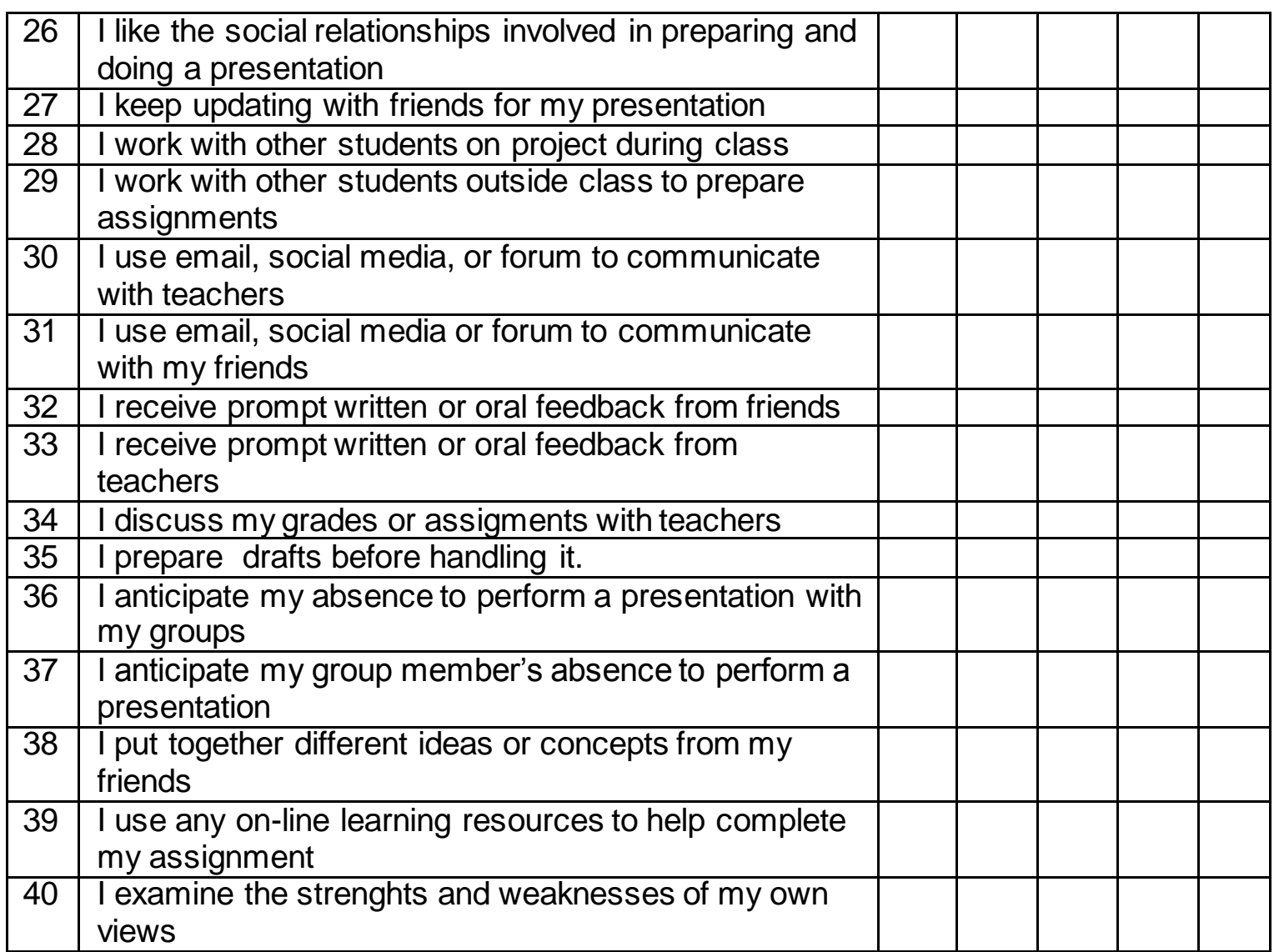

Adapted from Engagement and motivating: Questioning students on study-motivation, engagement and study strategies, Frauke Kubischta 